\title{
Religiosity and Corporate Risk-taking
}

\author{
Calvin W. H Cheong \\ Faculty of Business, Design and Arts, Swinburne University of Technology Sarawak \\ Jalan Simpang Tiga, 93350 Kuching, Malaysia \\ Tel: 60-82-260-996Ｅmail: ccheong@swinburne.edu.my \\ Received: August 27, 2018 Accepted: Oct. 23, $2018 \quad$ Published: December 1, 2018 \\ doi:10.5296/ajfa.v10i2.13749 URL: https://doi.org/10.5296/ajfa.v10i2.13749
}

\begin{abstract}
This paper studies the influence of religiosity on corporate risk-taking. The study uses unique micro-level data on religious devotion and distinguishes between manager religiosity, firm intrinsic religiosity, firm extrinsic religiosity, and social capital. Analysis shows that manager religiosity is associated with lower risk-taking. Firm intrinsic religiosity however, moderates this association. Further analysis shows that managers of Islamic firms are more likely to make risky decisions as compared to managers of other firms due to socio-religious pressure. Manager religiosity is also associated with lower firm equity risk. The results also suggest that strong external monitoring weakens the negative relationship between religiosity and risk-taking. This study shows how religious managers may be a double-edged sword. Religious managers are not risk-takers but are susceptible to social pressure. They are however, also more well-adjusted to a changing environment which inspires confidence in the markets.
\end{abstract}

Keywords: Religiosity, Religion, Risk-taking, Firm Risk, Market Confidence, Institutional Ownership 


\section{Introduction}

Corporations face increasing pressure to be more culturally inclusive by increasing gender, racial, and/or religious diversity of its employees. Although well-intentioned, little is known on the effects of such policies. Investigation into the effects of diversity (e.g. gender and race) on business and economic behavior have been made but Stern (2000), Schultz et al. (2000), Hilary and Hui (2009), Gul and $\mathrm{Ng}$ (2016), and Jiang et al. (2015) notwithstanding, not much has been said about religion. As one's religious beliefs explains one's economic attitudes, behaviors, and decisions (Iannacone, 1998), the religious beliefs of managers too have an impact on their decisions at work. A missing element from these studies however, is one's devotion to religion. Distinction should be made between those who are genuine followers of the faith, those who are pressured to, or because the law requires it (Note 1) (Granger et al., 2014). Additionally, as social norm theory suggests (Cialdini and Goldstein 2004) the effects of firm intrinsic and firm extrinsic religiosity need to be considered as well. Both forms of firm religiosity are primarily related to the environment that nourishes religious activities and devotion and has been found to play a major role in influencing and guiding attitudes and behaviors (Kohlberg 1984; Sunstein,1996).

Furthermore, most if not all prior studies have exclusively focused on the Abrahamic religions. Religious philosophy and its practice is however, multi-faceted. The Abrahamic religions typically preach the existence of one Supreme Being whom their followers worship and communicate with in hopes of achieving salvation or eternal life. The polytheistic religions (e.g. Hinduism, Buddhism, and Taoism) in contrast focus on 'a philosophy of life'; preaching the virtues of detachment, compassion, and karma to achieve enlightenment. To further our understanding of religious influence on corporate behavior, an examination of each religion and its effects on manager risk-taking behavior and firm risk is required.

This paper is an improvement over prior studies as I first examine manager religiosity i.e. the manager's devotion to religion, and its association with risk-taking. I then examine whether a firm's intrinsic religiosity has a moderating effect on manager religiosity and risk-taking, and is associated with lower firm risk, after controlling for its extrinsic religiosity, and social capital. I include firm religiosity in studying risk-taking since it directly affects firm behavior and the market is likely to take these into account when assessing the firm's strategic choices. This study also explores the effects of institutional ownership on the relationship between firm intrinsic religiosity and firm risk. This study examines these issues in Malaysia where multiculturalism (Note 2) is lived on a national scale. Management teams have representation from different ethnic and/or religious groups thereby avoiding the pitfalls of using a U.S.-centric and/or predominantly Christian sample besides allowing for investigation into how cultural entanglement, contamination and, pluralism can influence the dynamics of cultural influence and behavior (Cruz et al., 2017). Furthermore, using a Malaysian sample allows for investigating the effects each religion has on corporate risk-taking due to their much larger representation, as compared to other countries.

Using a dynamic panel system GMM, the results show that firms with high manager religiosity have lower levels of leverage, investment in fixed assets, and R\&D and advertising expenditure. This relationship is stronger for firms with high intrinsic religiosity, after 
controlling for other determinants of risk-taking behavior including extrinsic religiosity, social capital, and other firm-specific attributes. I also hypothesized and show that the effect of manager and firm intrinsic religiosity on risk-taking is secondary to external institutional monitoring mechanism i.e. institutional ownership. I also examined the effects of firm religion on risk-taking behavior. Though Muslim managers are the most religious, Islamic firms are most likely to engage in risky behavior. Interestingly, the relationship between manager religiosity and advertising expenditure was significantly positive, with firm intrinsic religiosity having a strong moderating effect on this relationship. Substituting the measures of risk-taking with firm equity risk shows that high firm intrinsic religiosity lowered total and systematic risk while high manager religiosity lowered systematic and idiosyncratic risk. Strong presence of an external monitor also negates the effects of religion on firm equity risk. Additionally, Islamic firms with high manager religiosity experience greater idiosyncratic risk but face lower total and systematic risk. Firms of other religions with high manager religiosity meanwhile experience lower idiosyncratic risk.

This paper extends the literature on the role of religion within markets in a few ways. First, this study makes use of unique micro-level data to take into account each manager's religious devotion and investigates how their devotion affects risk-taking behavior. Additionally, this study accounts for the firm's socio-religious environment and how it influences the risk-taking behavior of either the manager, the firm, or both. Second, using a pluralistic market sample furthers our understanding of the risk-religion relationship in a cross-cultural context, allowing examination of the influence of different religions on risk-taking separately. I argue that we can no longer make sweeping statements regarding religious influence on corporate behavior, particularly in an emerging market. Third, this study explores the influence of religion on the financial market as well, which has not been considered in prior studies. Finally, this paper contributes to the external monitoring literature by providing evidence that a strong presence of institutional investors can negate the influence of religion on within-firm and market decisions.

The rest of this paper is as follows. Section 2 provides a review of related studies and hypotheses development. Section 3 describes the data and methodology. Results are in Section 4. Section 5 discusses the findings on the relationship between religiosity and risk-taking behavior. Section 6 concludes.

\section{Literature Review}

\subsection{Religiosity and Behavior}

Religiosity is defined as a belief in God followed by a commitment to follow principles believed to be set by God (McDaniel and Burnett, 1990). It is widely understood that religion is strongly tied to morality, in that religion prescribes morality (Geyer and Baumeister, 2005) and drives behavior. The impact of religious norms, virtues, and ethics on human behavior has been widely acknowledged in the social sciences. In exploring the relationship between religiosity and economic outcomes (Shariff and Norenzayan, 2007; Norenzayan and Shariff, 2008) and business behavior (Stern, 2000; Schultz et al., 2000) the literature asociates stronger religiosity with greater risk-aversion. 
Distinction is also made between intrinsic and extrinsic orientations of religiosity. In a business context, intrinsic religiosity drives managerial behavior while extrinsic religiosity provides the environmental or contextual setting for managers to behave (Benabou and Tirole, 2003). Intrinsic religious practices and values have important consequences for economic development. As social norms, values, and even behavior can be transmitted through interactions within organized religious groups (Brammer et al., 2007), repeated interaction by attending social and religious ceremonies further strengthens their religiosity, social beliefs and values (Parboteetah et al., 2008). Hilary and Hui (2009) extend the religiosity literature by investigating its effects on managerial decisions, concluding that companies located in U.S. counties that have higher intrinsic religiosity are more risk-averse. Minton et al. (2015) similarly found that religious individuals are more likely to display sustainable behaviors (e.g. recycling, purchasing 'green' supplies).

Extrinsic religiosity is the environment that feeds religious activity. Studies on extrinsic religiosity find that both culture and socially endorsed norms influence and guide attitudes and behaviors (Barro and McCleary 2003; Festre 2010). Social attitudes displaying (dis)approval and specifying what ought (not) to be done are important determinants of human behavior (Stavrova and Siegers, 2014). La Porta et al. (1997) and Guiso et al. (2006) similarly argue that religious persons are more likely to comply with the understandings and expectations of the socio-religious norms of their environment to avoid punishment, stigmatization, and even isolation (Sunstein, 1996; Horne, 2009; Festre, 2010). Meanwhile, those that adhere and comply are rewarded with approval, support from the community, and respect (Stavrova and Siegers, 2014). Various studies have also suggested that business and social environment affect corporate decisions (Bedard and Johnstone 2004; Leventis et al. 2015).

\subsection{Religion and Risk-taking}

The role of religion in the markets and the social sciences have been studied over the years. Strong convictions of faith and religion are also associated with virtuous economic attitudes such as trust in others, trust in the government and legal system, and the belief that market outcomes are fair (Guiso et al., 2003). By extension, Stulz and Williamson (2003) found countries that are predominantly Catholic to display lower levels of creditor protection rights, partly due to the anti-usury culture prevalent in Catholic teachings. Generally, religious people are risk-averse. Iannacone (1998) for example, found religion to have a strong impact on one's inclination to commit crimes, consume drugs and alcohol, and engage in premarital sex. Miller and Hoffman (1995) found a negative correlation between religiosity and self-reported attitudes towards risk and danger. Religious individuals are also less inclined to gamble (Diaz, 2000). Why are religious people risk-averse? The literature seems to suggest that it may be anxiety and the fear of uncertainty that makes them drawn to religion (Miller and Hoffmann, 1995), using religion as a spiritual anchor to ease their fears. Followers of polytheistic religions also appear to be less risk-averse as compared to followers of Abrahamic religions owing to its philosophy of acceptance of uncertainty (Miller, 2000). In studying the risk-taking behavior of family firms, Jiang et al. (2015) similarly found firms with founders who professed an Abrahamic faith to be more risk-averse, while firms with 
founders who followed an Eastern religion did not appear to have a specific preference for risk However, recent studies (Sedikides and Gebauer, 2010; Gebauer et al., 2012) show that religious people are more confident, more psychologically adjusted, and highly valued in society exuding calm and inspiring confidence in others.

\subsection{Research Gap}

The contribution of Jiang et al. (2015) on the influence of religion on corporate decision-making is significant but there are still some matters that need to be addressed. First, they did not take into consideration the effects of extrinsic religiosity. Social norm theory posits that managers are affected by (religious) norms in their local geographic area. Since extrinsic religiosity has a significant role in developing individual attitudes and behaviors, and eventually, corporate behavior as well, a firm's risk-taking behaviour may either be extrinsically or intrinsically driven (Cheong et al., 2017) or both. Second, they contend that it is difficult to determine how religious a firm's decision makers are, especially in public-listed firms. As a result, the amount of authority a manager has over policy is difficult to determine. The present study addresses this issue by examining the religiosity of all levels of management. Third, although they made effort in identifying the religious adherence of the firm's founder, categorizing them simply as Western or Eastern does account for the subtle nuances between religions. Fourth, this study not only examines the religiosity of its top management team, but that of middle and lower managers as well, controlling for extrinsic religiosity and social capital. Finally, this study also examines the influence of different religions on firm risk-taking behavior.

\subsection{Hypotheses Development}

The literature argues that there should be a negative relationship between religiosity and risky behavior. Generally, it is hypothesized that firms with religious managers will exhibit lower levels of risk-taking than firms manned by non-religious managers. Specifically, this study observes a number of risk-taking measures to test this general hypothesis more specifically.

First, religious managers choose to hold low levels of debt in order to maintain low risk of default (Anderson and Reeb, 2003), hypothesis 1a is stated as:

H1a: Firms with religious managers (i.e. high manager religiosity) have lower levels of leverage than firms with nonreligious managers (i.e. low manager religiosity).

Second, as risk-averse managers are likely to only invest in projects that are safest and provides the highest value to the firm, a conservative level of investment in fixed assets can also be an indicator of risk-aversion (Hilary and Hui, 2009). Therefore, hypothesis $1 \mathrm{~b}$ is stated as:

H1b: Firms with religious managers have lower levels of fixed asset investment than firms with nonreligious managers.

Finally, risk-averse managers are also less likely to invest in intangible assets as they have uncertain payoffs with salvage values that are almost always zero (Jiang et al., 2015). Morck et al. (1988) contend that R\&D and advertising expenditures are key intangibles for a firm. Therefore, hypothesis $1 \mathrm{c}$ is stated as: 
H1c: Firms with religious managers have lower levels of intangible assets i.e. R\&D and advertising expenditures, than firms with nonreligious managers.

Manager religiosity however, does not necessarily stem from within themselves but also the religiosity of their immediate social circle and of the external environment (i.e. firm intrinsic religiosity). This has been shown to have an impact on managers' risk attitudes (Jaggi and Xin, 2014; Jha and Chen, 2015). Therefore, hypothesis 2 is stated as:

H2: The negative relationship between manager religiosity and risk-taking is stronger for firms with high intrinsic religiosity, after controlling for firm extrinsic religiosity and social capital

A study on the firm's external environment on risk-taking is incomplete without considering external monitoring mechanisms. An important external monitor considered here is the role of institutional ownership. Institutional ownership lowers agency costs (Bushee and Noe, 2000) as they are more knowledgeable and actively participate in strategic decision-making (Graves and Waddock, 1990). As a result, firms with higher levels of institutional ownership engage in less risky behavior and experience lower risk (Jafarinejad et al., 2015; Barinov, 2017). Hypothesis 3 can thus be stated as:

H3: The negative relationship between manager religiosity and risk taking is weaker for firms with higher levels of institutional ownership, after controlling for firm intrinsic religiosity, firm extrinsic religiosity, and social capital.

The final hypothesis is motivated by the findings of Cheong and Sinnakkannu (2014) and Jiang et al. (2015). The former found significant differences in the performance of firms with boards that consisted of only one ethnicity. Jiang et al. (2015) similarly found differences in the risk-aversion between firms with founders that professed a Western and Eastern faith. Since no prior study has studied the influence of different religions (i.e. Islam, Christianity, Buddhism, Hinduism) in this context separately, hypothesis 4 is stated in the null as follows:

H4: There is no difference in the risk-taking behavior of firms of different religions, after controlling for manager religiosity, firm intrinsic religiosity, firm extrinsic religiosity, and social capital.

\section{Data \& Methodology}

\subsection{Manager Religiosity}

Data for all religion-based variables were obtained from a survey conducted by a private research and consulting institute. The survey is part of a broader ongoing survey that seeks to provide a clearer understanding of corporate issues prevalent in a pluralistic (Note 3) market to make policy recommendations to the government on the promotion and guidance towards development of enterprises. The survey was conducted every year for 4 years from 2013 to 2016 (Note 4). The respondents were managers from all three levels of management in Malaysian public firms. The response rate to the survey was $89.5 \%$. The section on religion in the survey comprised of self-reported questions on personal practice, attendance at religious institutions, participation of events and ceremonies, understanding of the faith, and devotion and propagating the faith. Each category was scored out of 20 with a combined total of 100. The higher the score, the more religious the manager. A manager religiosity index was 
then constructed from the scores of each manager. The index is a weighted index. The weights are assigned depending on the level of influence each category of management (top, middle, low) has on business processes. As the sample firms are public firms, the level of authority top management (i.e. the board of directors) have on executing firm policies are hard to ascertain (Bertrand and Schoar, 2003). Rather, studies suggest that it is the middle managers that have a greater influence on effective execution of policy (Moss, 1982; Mollick, 2012). Middle managers are thus assigned a weight of 3, top managers 2, and low-level managers 1. Since subordinate attitudes can shape or even restrain a manager's influence (Grant et al., 2011) the religion scores of each management level is scaled by the number of subordinates.

\subsection{Firm Religiosity and Attributes}

The dataset also contains information on religious adherence and social activities among the general populace. This allows for the consideration of firm intrinsic religiosity, defined as the percentage of religious adherents in the population of the district where the sample firm is headquartered (Hilary and Hui, 2009). Firm extrinsic religiosity is defined as the number of religious institutions in the district where the sample firm is headquartered ( $\mathrm{Gul}$ and $\mathrm{Ng}$, 2016). Social capital is in the form of a social capital index. The index is constructed following the method employed by Rupasingha and Goetz (2008) and Jha and Chen (2015).

The survey also provided data for the dependent variables in this study i.e. leverage, fixed assets, R\&D and advertising expenditure. The survey also contained information on each firm's return on equity, size, manager age, education and experience. Since the board of directors were also respondents in the survey, board-specific attributes that have an impact on firm risk must also be controlled for. These are board size (Sah and Stiglitz, 1986; 1991), board independence (Fama and Jensen, 1983) and director connectedness (Fich and Shivdasani, 2007; Masulis and Mobbs, 2014). Variable definitions are in Table A1 of Appendix A. 


\subsection{A simple visualization of religiosity and risk-taking}

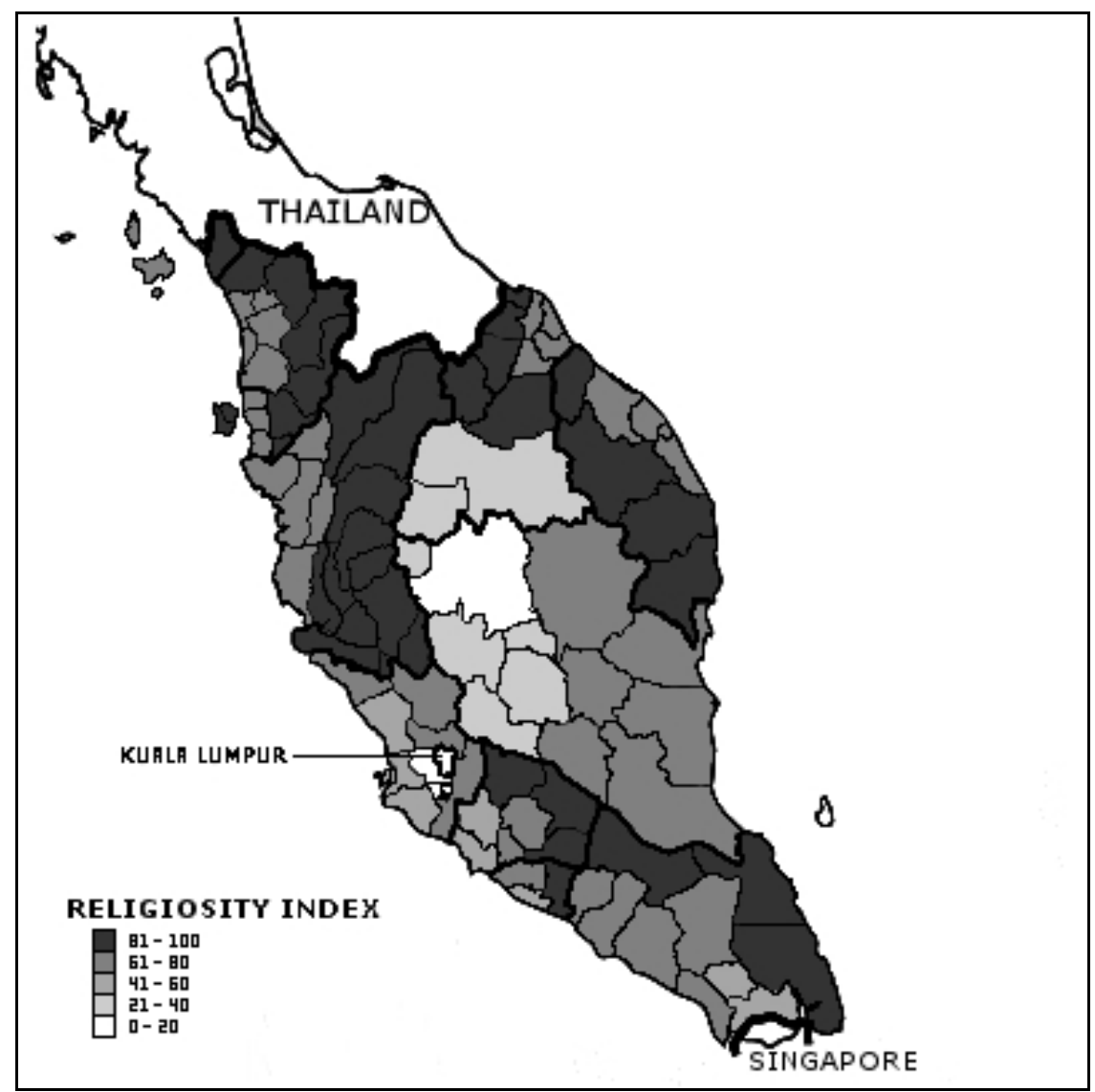

Figure 1. Geographic Variation of Manager Religiosity across Peninsular Malaysia, by district for the year 2016 (Source: author's own)

Figure 1 shows manager religiosity scores in Peninsular Malaysia(Note 5) at the district level for the year 2016. The figures for 2013, 2014, and 2015 are qualitatively similar and thus not shown. Correlation between these 3 years and 2016's scores are $0.91,0.93$, and 0.92 respectively. Variation in manager religiosity is apparent. Districts in the north and along the east coast score the highest. Those along the west coast, particularly in the capital city of Kuala Lumpur scored the lowest. The district at centre has no religiosity score as no firms were headquartered there. Generally, Figure 1 shows the significance of religion in the country. Apart from the metropolis, manager religiosity is relatively high across all districts.

\subsection{Endogeneity in the risk-religion relationship}

Establishing a causal relationship between religiosity and risk-taking is challenging as two sources of endogeneity are likely to bias the estimates. First, omitted unobservable fixed and time-varying firm characteristics may affect the manager appointment process and firm risk-taking. Risk-averse firms may choose to employ managers with diverse religious backgrounds but it could also be that such firms attract managers from diverse religious backgrounds. Omitted unobservable variables in this instance may result in a spurious interpretation of religion and risk-taking. Second, the direction of causality between 
risk-taking and manager religiosity is not clear ex-ante. Wintoki et al. (2012) and Cicero et al. (2013) show that reverse causality issues surrounding board characteristics are dynamic i.e. instead of manager religiosity affecting firm risk-aversion, it is risk-aversion that affects manager religiosity. Farrell and Hersch (2005) provides an example of how female directors may choose to serve in lower risk firms as a result of their higher level of risk aversion. In this study, there is therefore a chance that current manager religiosity is influenced by past realizations of firm risk.

Endogeneity issues are typically resolved through identification of instrumental variables that explain manager religiosity but is also exogenous to risk-taking. However, identifying a truly exogenous variable is near impossible. Due to the dynamic nature of the endogeneity issues and the difficulty in identifying truly exogenous suitable instruments, this study uses a dynamic panel system GMM (DPS-GMM) estimator (Arellano and Bover, 1995; Blundell and Bond, 1998) to account for the influence of unobserved heterogeneity and past realizations of risk-taking on manager religiosity and current risk-taking. Firm risk is highly correlated across time (Sila et al., 2016). As such, the estimator is only consistent when the relationship between past and present risk weakens over time over a long sample period. Owing to the short sample period and the dynamism of the relationship studied here, the DPS-GMM is more appropriate.

\section{Results}

\subsection{Summary Statistics}

Table 1 provides the summary statistics of the variables used in this study. 
Table 1. Summary Statistics

\begin{tabular}{|c|c|c|c|c|c|c|c|c|c|c|}
\hline & \multicolumn{5}{|c|}{ Full Sample } & \multicolumn{5}{|c|}{ Manager Religiosity } \\
\hline \multicolumn{11}{|l|}{ Religiosity Measures } \\
\hline Manager Religiosity & 71.381 & 4.111 & 18.753 & 65.223 & 84.372 & & & & & \\
\hline Firm intrinsic religiosity & 0.493 & 0.138 & 0.227 & 0.525 & 0.927 & 0.155 & 0.278 & 0.555 & 0.763 & 0.849 \\
\hline Firm extrinsic religiosity & 15.844 & 3.334 & 7.848 & 16.331 & 24.512 & 6.381 & 12.464 & 16.155 & 19.758 & 23.816 \\
\hline \multicolumn{11}{|l|}{ Risk Measures } \\
\hline Leverage & 0.151 & 0.092 & 0.018 & 0.152 & 0.281 & 0.284 & 0.217 & 0.178 & 0.125 & 0.103 \\
\hline Fixed assets & 0.045 & 0.108 & 0.051 & 0.065 & 0.123 & 0.138 & 0.113 & 0.074 & 0.055 & 0.039 \\
\hline \multicolumn{11}{|l|}{ Board Characteristics } \\
\hline Board size & 8.601 & 2.032 & 3.541 & 7.964 & 10.110 & 6.332 & 7.013 & 7.248 & 8.131 & 8.222 \\
\hline Board independence & 4.023 & 0.955 & 2.519 & 3.884 & 4.588 & 2.321 & 2.899 & 3.555 & 4.031 & 4.311 \\
\hline Director connectedness & 2.001 & 0.811 & 1.257 & 1.858 & 2.537 & 2.348 & 2.111 & 1.768 & 1.552 & 1.325 \\
\hline \multicolumn{11}{|l|}{ Firm Characteristics } \\
\hline Return on equity & 0.015 & 0.431 & -0.333 & 0.024 & 0.398 & -0.219 & 0.083 & 0.154 & 0.218 & 0.259 \\
\hline $\operatorname{Ln}(1+$ sales growth $)$ & 0.085 & 0.211 & 0.001 & 0.067 & 0.188 & 0.137 & 0.115 & 0.098 & 0.072 & 0.056 \\
\hline
\end{tabular}

This table reports summary statistics for the full sample and subsamples by the manager religiosity score. The sample comprises 3,280 firm-year observations from 820 firms for the 4-year sample period, 2013 - 2016. Data for all variables are obtained from the survey. Risk measures, board, and firm characteristics are then cross-checked with the Bloomberg database and the filed annual reports to ensure accuracy. Risk measures, ROE, FSIZE, CASH, and DIV are winsorized at the $1^{\text {st }}$ and $99^{\text {th }}$ percentiles. Variables are defined in Table A1.

Generally, managers in Malaysia are fairly religious with an average religiosity score of 71.381. Firm intrinsic and extrinsic religiosity is also relatively high with an average of approximately 50 percent of the district population adhering to a religion and 16 religious institutions in the district. Social capital across districts on average scored much lower. Table 1 shows relatively low mean values for the risk measures, suggesting a lower propensity for Malaysian firms to take risks. Table 1 also provides the mean values of all variables by manager religiosity. Positive monotonic relations between manager religiosity and firm intrinsic and extrinsic religiosity as well as social capital can be observed, suggesting that manager religiosity also stems from their external environment. Boards that are larger also tend to be more religious. Similarly, firms with more religious managers have boards with a 
greater number of independent directors and hold less external board seats. Firms with more religious managers seem to perform better in terms of ROE but are more conservative in terms of sales and surplus cash holdings. They are also more likely to declare dividends. Managers who are older and are more experienced also tend to be more religious.

There is also a negative monotonic relationship between manager religiosity and all four risk measures. A two-sample $t$-test (with unequal variances) was conducted to ascertain whether there exists a statistically significant difference in the level of risk-taking between firms with different manager religiosity scores. The test shows that an increase in manager religiosity tends to result in lower risk-taking (Note 6).

\subsection{Dynamic panel GMM estimation}

Table 2 provides the coefficient estimates of the DPS-GMM. In this estimation, two lags of each risk-taking measure is included in the model. The results provide evidence to suggest that manager religiosity reduces risk-taking behavior. All coefficients on manager religiosity are statistically significant and negative. The magnitude of effect manager religiosity has on each risk-taking measure is also considerable. For example, a 1-point increase in manager religiosity reduces leverage by 0.074 units. In comparison, the average leverage in the sample is 0.151 . Results of the Hansen test of overidentifying restrictions suggest that past values of the variables in the model are exogenous. Autocorrelation tests also show that there is no evidence of second-order autocorrelation in the residuals. The specification tests thus reveal that the instruments used in estimating the relationship between manager religiosity and risk-taking behavior are not endogenous. The estimates in Table 2 thus provides evidence to support H1a, H1b, and H1c. 
Table 2. Manager religiosity on risk-taking (DPS-GMM)

\begin{tabular}{|c|c|c|c|c|}
\hline Risk Measure $=$ & Leverage & Fixed Assets & R\&D & Advertising \\
\hline Manager Religiosity & $\begin{array}{l}-0.074 * * * \\
(0.155)\end{array}$ & $\begin{array}{l}-0.165^{* *} \\
(0.445)\end{array}$ & $\begin{array}{l}-0.003 * * \\
(0.343)\end{array}$ & $\begin{array}{l}-0.005 * * \\
(0.224)\end{array}$ \\
\hline Board Size & $\begin{array}{l}0.091 * \\
(0.015)\end{array}$ & $\begin{array}{l}0.131 * * \\
(0.122)\end{array}$ & $\begin{array}{l}0.012 * \\
(0.252)\end{array}$ & $\begin{array}{l}0.016^{*} \\
(0.154)\end{array}$ \\
\hline Board Independence & $\begin{array}{l}-0.177 * * \\
(0.189)\end{array}$ & $\begin{array}{l}-0.212 * * \\
(0.213)\end{array}$ & $\begin{array}{l}0.019 \\
(0.311)\end{array}$ & $\begin{array}{l}0.021 \\
(0.222)\end{array}$ \\
\hline Director Connectedness & $\begin{array}{l}0.018 \\
(0.345)\end{array}$ & $\begin{array}{l}-0.318 \\
(0.247)\end{array}$ & $\begin{array}{l}0.011 \\
(0.251)\end{array}$ & $\begin{array}{l}0.008 \\
(0.365)\end{array}$ \\
\hline Return on Equity & $\begin{array}{l}0.227^{*} \\
(0.451)\end{array}$ & $\begin{array}{l}0.333 * * \\
(0.276)\end{array}$ & $\begin{array}{l}0.015^{*} \\
(0.318)\end{array}$ & $\begin{array}{l}0.013^{*} \\
(0.422)\end{array}$ \\
\hline Ln(1 + Sales Growth $)$ & $\begin{array}{l}0.141 * \\
(0.133)\end{array}$ & $\begin{array}{l}0.458^{*} \\
(0.387)\end{array}$ & $\begin{array}{l}0.017^{*} \\
(0.219)\end{array}$ & $\begin{array}{l}0.015^{*} \\
(0.331)\end{array}$ \\
\hline Surplus Cash & $\begin{array}{l}-0.318^{*} \\
(0.222)\end{array}$ & $\begin{array}{l}-0.517 * * \\
(0.338)\end{array}$ & $\begin{array}{l}-0.026 * * \\
(0.652)\end{array}$ & $\begin{array}{l}-0.024 * * \\
(0.443)\end{array}$ \\
\hline Dividends & $\begin{array}{l}-0.011 \\
(0.234)\end{array}$ & $\begin{array}{l}-0.138 \\
(0.159)\end{array}$ & $\begin{array}{l}-0.001 \\
(0.245)\end{array}$ & $\begin{array}{l}-0.003 \\
(0.318)\end{array}$ \\
\hline Manager Age & $\begin{array}{l}-0.115^{*} \\
(0.177)\end{array}$ & $\begin{array}{l}0.144 * \\
(0.213)\end{array}$ & $\begin{array}{l}-0.051 * \\
(0.563)\end{array}$ & $\begin{array}{l}-0.029 * \\
(0.481)\end{array}$ \\
\hline Manager Experience & $\begin{array}{l}0.187^{*} \\
(0.259)\end{array}$ & $\begin{array}{l}0.383 * \\
(0.215)\end{array}$ & $\begin{array}{l}0.008 * \\
(0.404)\end{array}$ & $\begin{array}{l}0.003 * \\
(0.391)\end{array}$ \\
\hline Risk Measure (lag 1) & $\begin{array}{l}0.444 * * * \\
(0.314)\end{array}$ & $\begin{array}{l}0.513 \\
(0.332)\end{array}$ & $\begin{array}{l}0.411 * * * \\
(0.456)\end{array}$ & $\begin{array}{l}0.392 * * \\
(0.568)\end{array}$ \\
\hline Risk Measure (lag 2) & $\begin{array}{l}0.134 * \\
(0.438)\end{array}$ & $\begin{array}{l}0.211 \\
(0.313)\end{array}$ & $\begin{array}{l}0.186^{*} \\
(0.287)\end{array}$ & $\begin{array}{l}0.190 * \\
(0.333)\end{array}$ \\
\hline Observations & 3,280 & 3,280 & 3,280 & 3,280 \\
\hline Hansen $(\mathrm{df}=35)$ & 25.861 & 23.849 & 29.664 & 31.214 \\
\hline $\operatorname{AR}(1)$ & $1.589^{*}$ & $1.791 *$ & $2.335 * * *$ & $2.458 * * *$ \\
\hline $\operatorname{AR}(2)$ & 0.101 & 0.359 & 0.241 & 0.185 \\
\hline
\end{tabular}

This table reports two-step dynamic panel system GMM estimations of risk measures on manager religiosity and other control variables. All models include year and industry dummies. The null hypothesis for the Hansen test of overidentification is that all instruments are exogenous. $\operatorname{AR}(1)$ and $\operatorname{AR}(2)$ are test statistics for the null hypothesis that there is no serial correlation of orders 1 and 2 in the first-difference residuals. Finite-sample robust standard errors (Windmeijer, 2005) are in parentheses. ${ }^{* *},{ }^{* *}$, and $*$ denotes statistical significance at $1 \%, 5 \%$ and $10 \%$ respectively.

To examine the effects of firm intrinsic religiosity on manager religiosity and risk taking, the sample is split by level of firm intrinsic religiosity into three terciles. The DPS-GMM is then applied to the top and bottom terciles separately, controlling for firm extrinsic religiosity and social capital. The estimates are in Table 3. Coefficients for manager religiosity are insignificant when estimating for firms with low intrinsic religiosity (bottom panel). Results 
for the high firm intrinsic religiosity are significantly negative for all risk measures. Coefficients for firm extrinsic religiosity are significantly negative in the top panel while only marginally so in the bottom panel. Social capital meanwhile had no impact on risk-taking. One notable observation is the coefficient estimates on advertising expenditure are positive, contrary to expectations. I explore this in Section 4.6. Generally, the results show that the negative effect of manager religiosity on risk-taking is stronger for firms with high intrinsic religiosity, providing evidence to support $\mathrm{H} 2$.

Table 3. Manager religiosity on risk-taking, with high (low) firm intrinsic religiosity, controlling for firm extrinsic religiosity, and social capital (DPS-GMM)

\begin{tabular}{lllll}
\hline Risk Measure & Leverage & Fixed Assets & R\&D & Advertising \\
& & & & \\
\hline High Firm Intrinsic Religiosity $(\mathrm{N}=$ & & & & \\
1,105) & & & & \\
Manager Religiosity & $-0.078^{* * *}$ & $-2.666^{* *}$ & $-0.025^{* *}$ & $0.018^{* * *}$ \\
& $(0.257)$ & $(0.338)$ & $(0.413)$ & $(0.429)$ \\
Firm Extrinsic Religiosity & $-0.041^{* *}$ & $-0.551^{* *}$ & $-0.023^{*}$ & $0.010^{* *}$ \\
& $(0.443)$ & $(0.249)$ & $(0.291)$ & $(0.315)$ \\
Social Capital & 0.518 & 1.245 & 0.005 & 0.007 \\
& $(0.258)$ & $(0.678)$ & $(0.559)$ & $(0.341)$ \\
Control Variables & Yes & Yes & Yes & Yes \\
Industry Dummy & Yes & Yes & Yes & Yes \\
Year Dummy & Yes & Yes & Yes & Yes \\
Hansen $(d f=37)$ & 22.331 & 25.854 & 26.567 & 23.873
\end{tabular}

Low Firm Intrinsic Religiosity $(\mathrm{N}=$ $1,180)$

$\begin{array}{lllll}\text { Manager Religiosity } & -0.021 & -1.247 & -0.015 & 0.009 \\ \text { Firm Extrinsic Religiosity } & (0.348) & (0.289) & (0.315) & (0.287) \\ & -0.011^{*} & -0.238^{* *} & -0.012^{*} & 0.005^{*} \\ \text { Social Capital } & (0.443) & (0.331) & (0.458) & (0.388) \\ & 0.388 & 1.005 & 0.008 & 0.009 \\ \text { Control Variables } & (0.413) & (0.328) & (0.468) & (0.681) \\ \text { Industry Dummy } & \text { Yes } & \text { Yes } & \text { Yes } & \text { Yes } \\ \text { Year Dummy } & \text { Yes } & \text { Yes } & \text { Yes } & \text { Yes } \\ \text { Hansen }(d f=37) & \text { Yes } & \text { Yes } & \text { Yes } & \text { Yes } \\ & 22.857 & 24.329 & 23.335 & 28.511\end{array}$

This table reports two-step dynamic panel system GMM estimations of manage religiosity on risk-taking, controlling for institutional ownership. High (Low) firm intrinsic religiosity is defined as the top (bottom) tercile of the sample ranked based on the percentage of religious adherents in the population of the district where the sample firm is headquartered. Finite-sample robust standard errors (Windmeijer, 2005) are in parentheses. ***, $* *$, and $*$ denotes statistical significance at $1 \%, 5 \%$ and $10 \%$ respectively. 


\subsection{Institutional Ownership}

To examine the effects of prior year institutional ownership on manager religiosity and risk-taking, the sample is split by level of institutional ownership into three terciles. The DPS-GMM is then applied to the top and bottom terciles separately, controlling for firm intrinsic and extrinsic religiosity, and social capital. Results are in Table 4. The top (bottom) panel provides the DPS-GMM estimates for firms with high (low) prior year institutional ownership. None of the coefficients are statistically significant for the high institutional ownership sample save firm extrinsic religiosity. In the lower institutional ownership sample, all three religiosity coefficients are significantly negative across all risk-taking measures, except for advertising expenditure where it was significantly positive. Social capital remained statistically insignificant. The results in Table 4 suggests that external monitoring mechanisms have a direct impact on manager behavior but no obvious impact on social capital and extrinsic religiosity since they can only influence manager behavior but cannot control how the environment affects manager behavior (Gul and $\mathrm{Ng}, 2016$ ). The results in Table 4 shows that when external monitoring is weak, manager religiosity is a key determinant of risk-taking, and that external monitoring and manager religiosity are substitutes to moderating risk-taking, providing evidence to support $\mathrm{H} 3$. 
Table 4. Effects of manager religiosity on risk-taking, controlling for institutional ownership (DPS-GMM)

\begin{tabular}{|c|c|c|c|c|}
\hline Risk Measure & Leverage & Fixed Assets & $\mathrm{R} \& \mathrm{D}$ & Advertising \\
\hline \multicolumn{5}{|c|}{$\begin{array}{l}\text { High Institutional Ownership }(\mathrm{N}= \\
1,151)\end{array}$} \\
\hline Manager Religiosity & $\begin{array}{l}-0.018 \\
(0.313)\end{array}$ & $\begin{array}{l}-1.055 \\
(0.349)\end{array}$ & $\begin{array}{l}-0.001 \\
(0.458)\end{array}$ & $\begin{array}{l}0.003 \\
(0.329)\end{array}$ \\
\hline Firm Intrinsic Religiosity & $\begin{array}{l}-0.015 \\
(0.661)\end{array}$ & $\begin{array}{l}-0.165 \\
(0.399)\end{array}$ & $\begin{array}{l}-0.001 \\
(0.314)\end{array}$ & $\begin{array}{l}0.002 \\
(0.406)\end{array}$ \\
\hline Firm Extrinsic Religiosity & $\begin{array}{l}-0.022 * * \\
(0.533)\end{array}$ & $\begin{array}{l}-0.213 * * * \\
(0.283)\end{array}$ & $\begin{array}{l}-0.006^{*} \\
(0.298)\end{array}$ & $\begin{array}{l}0.005^{*} \\
(0.355)\end{array}$ \\
\hline Social Capital & $\begin{array}{l}0.278 \\
(0.277)\end{array}$ & $\begin{array}{l}1.115 \\
(0.681)\end{array}$ & $\begin{array}{l}0.003 \\
(0.553)\end{array}$ & $\begin{array}{l}0.005 \\
(0.308)\end{array}$ \\
\hline Control Variables & Yes & Yes & Yes & Yes \\
\hline Industry Dummy & Yes & Yes & Yes & Yes \\
\hline Year Dummy & Yes & Yes & Yes & Yes \\
\hline $\begin{array}{l}\text { Low Institutional Owner } \\
1,280)\end{array}$ & & & & \\
\hline Manager Religiosity & $\begin{array}{l}-0.051 * * \\
(0.308)\end{array}$ & $\begin{array}{l}-1.516^{* *} \\
(0.338)\end{array}$ & $\begin{array}{l}-0.007 * * \\
(0.413)\end{array}$ & $\begin{array}{l}0.008 * * \\
(0.429)\end{array}$ \\
\hline Firm Intrinsic Religiosity & $\begin{array}{l}-0.048 * * \\
(0.613)\end{array}$ & $\begin{array}{l}-0.186^{* *} \\
(0.308)\end{array}$ & $\begin{array}{l}-0.002 * \\
(0.277)\end{array}$ & $\begin{array}{l}0.005 * * * \\
(0.371)\end{array}$ \\
\hline Firm Extrinsic Religiosity & $\begin{array}{l}-0.018^{*} \\
(0.419)\end{array}$ & $\begin{array}{l}-0.144^{*} \\
(0.668)\end{array}$ & $\begin{array}{l}-0.003 * \\
(0.391)\end{array}$ & $\begin{array}{l}0.002 * \\
(0.328)\end{array}$ \\
\hline Social Capital & $\begin{array}{l}0.332 \\
(0.270)\end{array}$ & $\begin{array}{l}1.439 \\
(0.628)\end{array}$ & $\begin{array}{l}0.003 \\
(0.438)\end{array}$ & $\begin{array}{l}0.005 \\
(0.325)\end{array}$ \\
\hline Control Variables & Yes & Yes & Yes & Yes \\
\hline Industry Dummy & Yes & Yes & Yes & Yes \\
\hline Year Dummy & Yes & Yes & Yes & Yes \\
\hline
\end{tabular}

This table reports two-step dynamic panel system GMM estimations of manager religiosity on risk-taking, controlling for institutional ownership. High (Low) institutional ownership is defined as the top (bottom) tercile of the sample ranked based on percentage of institutional ownership in the prior fiscal year. Endogenous variables are instrumented by two of their past values. Finite-sample robust standard errors (Windmeijer, 2005) are in parentheses. $* * * * *$, and $*$ denotes statistical significance at $1 \%, 5 \%$ and $10 \%$ respectively.

\subsection{Firm Religion}

To investigate the influence each religion has on risk-taking, the sample firms are first sorted according to firm religion. Firm religion is defined as the professed religion of at least $60 \%$ of the surveyed managers. For example, if at least 60 percent of the managers are Muslims, the firm's religion is therefore Islam. 
Table 5. Mean Values by Firm Religion

\begin{tabular}{lllll}
\hline & \multicolumn{3}{l}{ Firm Religion } & \\
\cline { 2 - 5 } & Islam & Christianity & Buddhism & Hinduism \\
\hline Religiosity Measures & & & & \\
Manager Religiosity & 81.235 & 72.311 & 69.458 & 73.643 \\
Firm intrinsic religiosity & 0.853 & 0.612 & 0.578 & 0.663 \\
Firm extrinsic religiosity & 18.221 & 12.464 & 10.203 & 9.584 \\
Social capital & 3.555 & 2.784 & 2.557 & 2.893 \\
& & & & \\
Risk Measures & & & & \\
Leverage & 0.495 & 0.158 & 0.205 & 0.223 \\
Fixed assets & 0.581 & 0.231 & 0.253 & 0.224 \\
R\&D expenditure & 0.011 & 0.122 & 0.108 & 0.095 \\
Advertising expenditure & 0.256 & 0.213 & 0.208 & 0.201 \\
& & & & \\
Board Characteristics & & & & \\
Board size & 9.015 & 7.123 & 7.556 & 7.312 \\
Board independence & 2.111 & 3.587 & 4.005 & 3.223 \\
Director connectedness & 3.018 & 2.015 & 2.187 & 2.039 \\
& & & & \\
Firm Characteristics & & & & \\
Return on equity & -0.157 & 0.065 & 0.050 & 0.010 \\
Ln(1 + sales growth) & 0.085 & 0.109 & 0.099 & 0.101 \\
Surplus cash & 0.005 & 0.055 & 0.067 & 0.034 \\
Dividends & 0.157 & 0.264 & 0.174 & 0.351 \\
Manager age & 45.889 & 41.123 & 46.481 & 42.331 \\
Manager experience & 2.51 & 3.85 & 5.12 & 3.53 \\
\hline
\end{tabular}

This table reports the mean values for the full sample sorted by firm religion. The sample comprises 3,280 firm-year observations from 820 firms for the 4-year sample period, 2013 - 2016. Data for all variables are obtained from the survey. Risk measures, board, and firm characteristics are then cross-checked with the Bloomberg database and the filed annual reports to ensure accuracy. Risk measures, ROE, FSIZE, CASH, and DIV are winsorized at the $1^{\text {st }}$ and $99^{\text {th }}$ percentile values. Full summary statistics are in Table 1 . All variables are defined in Table A1.

The mean values in Table 5 suggest significant differences in risk-taking and firm characteristics across the four main religions. Religiosity scores of Islamic firms are the highest. However, the amount of leverage, fixed assets, and advertising expenditure of Islamic firms are also disproportionately larger than other firms, although they also record the lowest R\&D expenditure. Their boards are the largest but also the least independent while their directors have the greatest connectedness. As for firms of other religions, slight differences can be observed across all variables, especially those on religiosity and risk-taking but not to the extent of that seen for Islamic firms. 
Table 6. Effects of firm religion on risk-taking (DPS-GMM)

\begin{tabular}{|c|c|c|c|c|}
\hline Risk Measure & Leverage & Fixed Assets & R\&D & Advertising \\
\hline \multicolumn{5}{|l|}{$\operatorname{Islam}(\mathrm{N}=940)$} \\
\hline \multirow[t]{2}{*}{ Manager Religiosity } & $0.015 * * *$ & $0.853 * *$ & $0.000 *$ & $0.008 * *$ \\
\hline & $(0.358)$ & $(0.443)$ & $(0.648)$ & $(0.712)$ \\
\hline \multirow[t]{2}{*}{ Firm Intrinsic Religiosity } & $0.018 *$ & $0.523 * *$ & -0.001 & $0.018 * * *$ \\
\hline & $(0.216)$ & $(0.322)$ & $(0.583)$ & $(0.332)$ \\
\hline \multirow[t]{2}{*}{ Firm Extrinsic Religiosity } & $-0.005 *$ & $-0.335 * *$ & $-0.002 *$ & $0.008 * * *$ \\
\hline & $(0.325)$ & $(0.286)$ & $(0.189)$ & $(0.439)$ \\
\hline \multirow[t]{2}{*}{ Social Capital } & 0.321 & 0.224 & 0.018 & 0.003 \\
\hline & $(0.585)$ & $(0.335)$ & $(0.456)$ & $(0.333)$ \\
\hline \multicolumn{5}{|l|}{ Christianity $(\mathrm{N}=858)$} \\
\hline \multirow[t]{2}{*}{ Manager Religiosity } & $-0.038 * * *$ & $-1.115^{* *}$ & $-0.008 * *$ & $0.001 *$ \\
\hline & $(0.451)$ & $(0.503)$ & $(0.383)$ & $(0.267)$ \\
\hline \multirow[t]{2}{*}{ Firm Intrinsic Religiosity } & $-0.028 * *$ & $-1.088 * * *$ & $-0.007 *$ & $0.002 *$ \\
\hline & $(0.334)$ & $(0.228)$ & $(0.386)$ & $(0.239)$ \\
\hline \multirow[t]{2}{*}{ Firm Extrinsic Religiosity } & $-0.031 *$ & $-1.003 * * *$ & $-0.008 * *$ & $0.004^{*}$ \\
\hline & $(0.411)$ & $(0.287)$ & $(0.339)$ & $(0.384)$ \\
\hline \multirow[t]{2}{*}{ Social Capital } & 0.248 & 0.333 & 0.014 & 0.004 \\
\hline & $(0.573)$ & $(0.600)$ & $(0.617)$ & $(0.487)$ \\
\hline \multicolumn{5}{|l|}{ Buddhism $(\mathrm{N}=832)$} \\
\hline \multirow[t]{2}{*}{ Manager Religiosity } & $-0.054 * *$ & $-1.347 * *$ & $-0.010 *$ & $0.003 * *$ \\
\hline & $(0.341)$ & $(0.511)$ & $(0.287)$ & $(0.448)$ \\
\hline \multirow[t]{2}{*}{ Firm Intrinsic Religiosity } & $-0.027 * *$ & $-1.212 * * *$ & $-0.006^{*}$ & 0.002 \\
\hline & $(0.277)$ & $(0.379)$ & $(0.454)$ & $(0.348)$ \\
\hline \multirow[t]{2}{*}{ Firm Extrinsic Religiosity } & $-0.033 * * *$ & $-1.017^{*}$ & $-0.005 * *$ & 0.005 \\
\hline & $(0.453)$ & $(0.384)$ & $(0.462)$ & $(0.333)$ \\
\hline \multirow[t]{2}{*}{ Social Capital } & 0.298 & 0.387 & 0.004 & 0.002 \\
\hline & $(0.499)$ & $(0.513)$ & $(0.385)$ & $(0.457)$ \\
\hline
\end{tabular}


Table 6 continued

Hinduism $(\mathrm{N}=650)$

\begin{tabular}{lllll}
\hline Manager Religiosity & $-0.043^{* *}$ & $-1.221^{*}$ & $-0.011^{*}$ & $0.004^{*}$ \\
& $(0.383)$ & $(0.298)$ & $(0.314)$ & $(0.223)$ \\
Firm Intrinsic Religiosity & $-0.031^{* *}$ & $-1.314^{* * *}$ & -0.008 & $0.006^{* * *}$ \\
& $(0.441)$ & $(0.378)$ & $(0.417)$ & $(0.222)$ \\
Firm Extrinsic Religiosity & $-0.011^{*}$ & $-1.285^{* * *}$ & $-0.002^{*}$ & $0.003^{* * *}$ \\
& $(0.392)$ & $(0.333)$ & $(0.228)$ & $(0.414)$ \\
Social Capital & 0.319 & 0.425 & 0.001 & 0.008 \\
& $(0.378)$ & $(0.493)$ & $(0.242)$ & $(0.359)$ \\
Control Variables & & & & \\
Industry Dummy & Yes & Yes & Yes & Yes \\
Year Dummy & Yes & Yes & Yes & Yes \\
& Yes & Yes & Yes & Yes
\end{tabular}

This table reports two-step dynamic panel system GMM estimations of firm religion (Islam, Christianity, Buddhism, and Hinduism) on risk-taking measures. All models include year and industry dummiesFinite-sample robust standard errors (Windmeijer, 2005) are in parentheses. ${ }^{* *},{ }^{* *}$, and $*$ denotes statistical significance at the $1 \%, 5 \%$ and $10 \%$ respectively.

The results in Table 6 show the influence of firm religion on the relationship between religiosity and risk-taking. We see a significant positive relationship between manager religiosity and risk-taking for Islamic firms, contrary to the hypothesis. The coefficient estimates for firms of other religions meanwhile are qualitatively similar to those presented earlier and support the hypothesis that greater manager religiosity reduces risk-taking. There are however, obvious differences in the magnitude of effect. Buddhist firms are the least likely to take on risks as followed by Hindu and Christian firms. We can also see that the positive relationship between religiosity and advertising expenditure persists across all firm religions.

\subsection{Religion and Equity Risk}

Although religiosity may reduce managers' risky behavior but their lower-risk policies may not necessarily translate into less volatile stock prices. Stock price volatility is also driven by investor sentiments. Firms that behave in a manner that conforms to social expectations experience lower stock price volatility (Cheong et al., 2017). As religious managers are highly valued and inspire confidence (Gebauer et al., 2012) firms with religious managers should experience lower equity risk. To test this proposition, I observe three measures of equity risk: total risk, systematic risk, and idiosyncratic risk. Total risk is the standard deviation of daily stock returns over the preceding year. Systematic risk is the coefficient on the market portfolio from a market-model regression using the Kuala Lumpur Stock Exchange equally-weighted index. Idiosyncratic risk is the standard deviation of the residuals from the Fama-French three-factor model (Fama and French, 1993). All returns are exclusive of dividends. Returns data was sourced from Bloomberg. Annualizing total and idiosyncratic standard deviations was simply by multiplying them by the square root of 250 . Table 7 
provides the results of the DPS-GMM.

Table 7. Manager religiosity on firm equity risk (DPS-GMM)

\begin{tabular}{|c|c|c|c|}
\hline Risk Measure & Total Risk & $\begin{array}{l}\text { Systematic } \\
\text { Risk }\end{array}$ & $\begin{array}{l}\text { Idiosyncratic } \\
\text { Risk }\end{array}$ \\
\hline Manager Religiosity & $\begin{array}{l}-0.075 \\
(0.165)\end{array}$ & $\begin{array}{l}-0.328 * * * \\
(0.519)\end{array}$ & $\begin{array}{l}-0.111 * * * \\
(0.381)\end{array}$ \\
\hline Firm Intrinsic Religiosity & $\begin{array}{l}-0.115^{* * *} \\
(0.328)\end{array}$ & $\begin{array}{l}-0.522 * * \\
(0.653)\end{array}$ & $\begin{array}{l}-0.089 \\
(0.266)\end{array}$ \\
\hline Firm Extrinsic Religiosity & $\begin{array}{l}-0.134 \\
(0.551)\end{array}$ & $\begin{array}{l}-0.428 \\
(0.444)\end{array}$ & $\begin{array}{l}-0.140 \\
(0.315)\end{array}$ \\
\hline Social Capital & $\begin{array}{l}0.218 \\
(0.517)\end{array}$ & $\begin{array}{l}0.387^{*} \\
(0.610)\end{array}$ & $\begin{array}{l}0.112 \\
(0.266)\end{array}$ \\
\hline Board Size & $\begin{array}{l}0.108 \\
(0.333)\end{array}$ & $\begin{array}{l}0.184 * * \\
(0.348)\end{array}$ & $\begin{array}{l}0.203^{*} \\
(0.411)\end{array}$ \\
\hline Board Independence & $\begin{array}{l}-0.238 * * \\
(0.430)\end{array}$ & $\begin{array}{l}-0.400 * * \\
(0.222)\end{array}$ & $\begin{array}{l}-0.021 * * * \\
(0.163)\end{array}$ \\
\hline Director Connectedness & $\begin{array}{l}0.305 \\
(0.115)\end{array}$ & $\begin{array}{l}-0.284^{*} \\
(0.155)\end{array}$ & $\begin{array}{l}0.123 \\
(0.339)\end{array}$ \\
\hline Return on Equity & $\begin{array}{l}-0.215^{* *} \\
(0.383)\end{array}$ & $\begin{array}{l}-0.308 * * \\
(0.556)\end{array}$ & $\begin{array}{l}-0.110^{* * *} \\
(0.314)\end{array}$ \\
\hline $\operatorname{Ln}(1+$ Sales Growth $)$ & $\begin{array}{l}0.122 \\
(0.099)\end{array}$ & $\begin{array}{l}0.138 \\
(0.186)\end{array}$ & $\begin{array}{l}0.089 \\
(0.098)\end{array}$ \\
\hline Surplus Cash & $\begin{array}{l}0.266 \\
(0.199)\end{array}$ & $\begin{array}{l}0.377 \\
(0.496)\end{array}$ & $\begin{array}{l}0.163 * * \\
(0.832)\end{array}$ \\
\hline Dividends & $\begin{array}{l}-0.202 \\
(0.311)\end{array}$ & $\begin{array}{l}-0.148 \\
(0.249)\end{array}$ & $\begin{array}{l}-0.128 \\
(0.143)\end{array}$ \\
\hline Manager Age & $\begin{array}{l}-0.314 \\
(0.182)\end{array}$ & $\begin{array}{l}-0.166 \\
(0.304)\end{array}$ & $\begin{array}{l}-0.085 \\
(0.439)\end{array}$ \\
\hline Manager Experience & $\begin{array}{l}0.286 \\
(0.145)\end{array}$ & $\begin{array}{l}0.148 \\
(0.191)\end{array}$ & $\begin{array}{l}0.235^{* * * *} \\
(0.245)\end{array}$ \\
\hline Risk Measure (lag 1) & $\begin{array}{l}0.244 * * * \\
(0.121)\end{array}$ & $\begin{array}{l}0.396 * * \\
(0.150)\end{array}$ & $\begin{array}{l}0.256^{* * * *} \\
(0.189)\end{array}$ \\
\hline Risk Measure (lag 2) & $\begin{array}{l}0.131 \\
(0.226)\end{array}$ & $\begin{array}{l}0.159 \\
(0.189) \\
\end{array}$ & $\begin{array}{l}0.148 \\
(0.169) \\
\end{array}$ \\
\hline Observations & 3,280 & 3,280 & 3,280 \\
\hline Hansen $(\mathrm{df}=35)$ & 25.687 & 22.659 & 25.415 \\
\hline $\mathrm{AR}(1)$ & $2.132 * *$ & 1.228 & $3.554 * * *$ \\
\hline $\operatorname{AR}(2)$ & 1.028 & 1.335 & 1.546 \\
\hline
\end{tabular}

All specifications are as Table 2 above. ${ }^{* * *},{ }^{* *}$, and ${ }^{*}$ denotes statistical significance at $1 \%, 5 \%$ and $10 \%$ respectively.

The first column of Table 7 shows no statistically significant relationship between manager religiosity and total risk while firm intrinsic religiosity lowers total risk. In the second column, 
both manager and firm intrinsic religiosity lowers systematic risk while manager religiosity has a significant negative relationship with idiosyncratic risk. I repeat the DPS-GMM estimations by controlling for institutional ownership, and then investigating the impact of firm religion. The results are in Table 8 and 9.

Table 8. Effects of manager religiosity on firm equity risk, controlling for institutional ownership (DPS-GMM)

\begin{tabular}{|c|c|c|c|}
\hline Risk Measure & $\begin{array}{l}\text { Total } \\
\text { Risk }\end{array}$ & $\begin{array}{l}\text { Systematic } \\
\text { Risk }\end{array}$ & $\begin{array}{l}\text { Idiosyncratic } \\
\text { Risk }\end{array}$ \\
\hline \multicolumn{4}{|c|}{$\begin{array}{l}\text { High Institutional Ownership }(\mathrm{N}= \\
1,151)\end{array}$} \\
\hline Manager Religiosity & $\begin{array}{l}-0.115 \\
(0.228)\end{array}$ & $\begin{array}{l}-0.634 \\
(0.189)\end{array}$ & $\begin{array}{l}-0.120 \\
(0.307)\end{array}$ \\
\hline Firm Intrinsic Religiosity & $\begin{array}{l}-0.128 \\
(0.585)\end{array}$ & $\begin{array}{l}-0.565 * \\
(0.440)\end{array}$ & $\begin{array}{l}-0.135 \\
(0.299)\end{array}$ \\
\hline Firm Extrinsic Religiosity & $\begin{array}{l}-0.149 \\
(0.444)\end{array}$ & $\begin{array}{l}-0.408 \\
(0.319)\end{array}$ & $\begin{array}{l}-0.356 \\
(0.367)\end{array}$ \\
\hline Social Capital & $\begin{array}{l}0.245 \\
(0.190)\end{array}$ & $\begin{array}{l}0.486 \\
(0.556)\end{array}$ & $\begin{array}{l}0.253 \\
(0.322)\end{array}$ \\
\hline Control Variables & Yes & Yes & Yes \\
\hline Industry Dummy & Yes & Yes & Yes \\
\hline Year Dummy & Yes & Yes & Yes \\
\hline \multicolumn{4}{|c|}{$\begin{array}{l}\text { Low Institutional Ownership }(\mathrm{N}= \\
1,280)\end{array}$} \\
\hline Manager Religiosity & $\begin{array}{l}-0.218 \\
(0.188)\end{array}$ & $\begin{array}{l}-0.788 * * \\
(0.415)\end{array}$ & $\begin{array}{l}-0.233 * * \\
(0.300)\end{array}$ \\
\hline Firm Intrinsic Religiosity & $\begin{array}{l}-0.342 * * \\
(0.550)\end{array}$ & $\begin{array}{l}-0.663 * * \\
(0.275)\end{array}$ & $\begin{array}{l}-0.269 \\
(0.344)\end{array}$ \\
\hline Firm Extrinsic Religiosity & $\begin{array}{l}-0.250 * \\
(0.323)\end{array}$ & $\begin{array}{l}-0.518 * \\
(0.399)\end{array}$ & $\begin{array}{l}-0.411 \\
(0.376)\end{array}$ \\
\hline Social Capital & $\begin{array}{l}0.482 \\
(0.285)\end{array}$ & $\begin{array}{l}0.557 \\
(0.313)\end{array}$ & $\begin{array}{l}0.333 \\
(0.195)\end{array}$ \\
\hline Control Variables & Yes & Yes & Yes \\
\hline Industry Dummy & Yes & Yes & Yes \\
\hline Year Dummy & Yes & Yes & Yes \\
\hline
\end{tabular}

This table reports two-step dynamic panel system GMM estimations of manager religiosity on firm equity risk, controlling for institutional ownership. All specifications are as above. ***, **, and * denotes statistical significance at $1 \%, 5 \%$ and $10 \%$ respectively.

The estimates in Table 8 are qualitatively similar to those in Table 4 and 7 , even after controlling for institutional ownership. In the top panel, we see that manager religiosity as well as other religious factors have no statistically significant impact on firm risk. In the 
bottom panel, low institutional ownership firms only exhibited a significant negative relationship between firm intrinsic religiosity and total and systematic risk. Manager religiosity only has a significant negative relationship with idiosyncratic risk.

Table 9. Effects of firm religion on firm equity risk

\begin{tabular}{|c|c|c|c|}
\hline Risk Measure & Total Risk & $\begin{array}{l}\text { Systematic } \\
\text { Risk } \\
\end{array}$ & $\begin{array}{l}\text { Idiosyncratic } \\
\text { Risk }\end{array}$ \\
\hline \multicolumn{4}{|l|}{ Islam $(\mathrm{N}=940)$} \\
\hline Manager Religiosity & $\begin{array}{l}0.011 \\
(0.367)\end{array}$ & $\begin{array}{l}-0.866^{* * *} \\
(0.412)\end{array}$ & $\begin{array}{l}0.011 * * \\
(0.555)\end{array}$ \\
\hline Firm Intrinsic Religiosity & $\begin{array}{l}-0.015^{* * * *} \\
(0.222)\end{array}$ & $\begin{array}{l}-0.611 * * * \\
(0.286)\end{array}$ & $\begin{array}{l}-0.009 \\
(0.486)\end{array}$ \\
\hline Firm Extrinsic Religiosity & $\begin{array}{l}-0.003 \\
(0.345)\end{array}$ & $\begin{array}{l}-0.344 \\
(0.261)\end{array}$ & $\begin{array}{l}-0.003 \\
(0.201)\end{array}$ \\
\hline Social Capital & $\begin{array}{l}0.214 \\
(0.475)\end{array}$ & $\begin{array}{l}0.310 \\
(0.341)\end{array}$ & $\begin{array}{l}0.022 \\
(0.316)\end{array}$ \\
\hline \multicolumn{4}{|l|}{ Christianity $(\mathrm{N}=858)$} \\
\hline Manager Religiosity & $\begin{array}{l}-0.041 \\
(0.413)\end{array}$ & $\begin{array}{l}-1.223 * * \\
(0.511)\end{array}$ & $\begin{array}{l}-0.016^{* *} \\
(0.209)\end{array}$ \\
\hline Firm Intrinsic Religiosity & $\begin{array}{l}-0.031 \\
(0.355)\end{array}$ & $\begin{array}{l}-1.009 \\
(0.331)\end{array}$ & $\begin{array}{l}-0.011 \\
(0.448)\end{array}$ \\
\hline Firm Extrinsic Religiosity & $\begin{array}{l}-0.028 \\
(0.422)\end{array}$ & $\begin{array}{l}-1.011 \\
(0.384)\end{array}$ & $\begin{array}{l}-0.020 \\
(0.257)\end{array}$ \\
\hline Social Capital & $\begin{array}{l}0.235 \\
(0.559)\end{array}$ & $\begin{array}{l}0.311 \\
(0.676)\end{array}$ & $\begin{array}{l}0.018 \\
(0.558)\end{array}$ \\
\hline Buddhism $(\mathrm{N}=832)$ & & & \\
\hline Manager Religiosity & $\begin{array}{l}-0.035^{*} \\
(0.311)\end{array}$ & $\begin{array}{l}-1.441 * \\
(0.385)\end{array}$ & $\begin{array}{l}-0.025 * * \\
(0.196)\end{array}$ \\
\hline Firm Intrinsic Religiosity & $\begin{array}{l}-0.029 \\
(0.288)\end{array}$ & $\begin{array}{l}-1.243 \\
(0.388)\end{array}$ & $\begin{array}{l}-0.016 \\
(0.334)\end{array}$ \\
\hline Firm Extrinsic Religiosity & $\begin{array}{l}-0.038 \\
(0.449)\end{array}$ & $\begin{array}{l}-1.009 \\
(0.277)\end{array}$ & $\begin{array}{l}-0.011 \\
(0.237)\end{array}$ \\
\hline Social Capital & $\begin{array}{l}0.288 \\
(0.319)\end{array}$ & $\begin{array}{l}0.400 \\
(0.409)\end{array}$ & $\begin{array}{l}0.009 \\
(0.225)\end{array}$ \\
\hline
\end{tabular}


Table 9 continued

Hinduism $(\mathrm{N}=650)$

\begin{tabular}{llll}
\hline Manager Religiosity & -0.051 & $-1.099^{*}$ & $-0.016^{* * *}$ \\
& $(0.399)$ & $(0.301)$ & $(0.300)$ \\
Firm Intrinsic Religiosity & -0.027 & -1.044 & -0.010 \\
& $(0.271)$ & $(0.318)$ & $(0.481)$ \\
Firm Extrinsic Religiosity & -0.021 & -1.113 & -0.008 \\
& $(0.411)$ & $(0.322)$ & $(0.273)$ \\
Social Capital & 0.306 & 0.400 & 0.005 \\
& $(0.344)$ & $(0.413)$ & $(0.213)$ \\
Control Variables & & & \\
Industry Dummy & Yes & Yes & Yes \\
Year Dummy & Yes & Yes & Yes \\
& Yes & Yes & Yes
\end{tabular}

This table reports two-step dynamic panel system GMM estimations of firm religion (Islam, Christianity, Buddhism, and Hinduism) on firm equity risk. All specifications are as above. ***, **, and * denotes statistical significance at $1 \%, 5 \%$ and $10 \%$ respectively.

\subsection{The case of advertising}

Summary statistics and Table 1 show a negative relationship but estimates in Tables 3 to 6 show a positive relationship between manager religiosity and advertising expenditure. This could be the result of: (1) reverse causality i.e. advertising expenditure influences manager religiosity; (2) the contrary relationship is driven by other observable factors such as firm and board characteristics; and (3) the relationship is driven by other unobservable factors such as leadership styles and corporate culture. I investigate this by estimating a static model between manager religiosity and advertising expenditure using OLS and a fixed effects estimator. If the positive relationship was caused by observable factors, OLS estimates of manager religiosity on advertising expenditure would be insignificant once these factors were included. If it was caused by unobservable factors, this should be captured by the fixed effects.

OLS and fixed effects estimations are presented in Table 10. OLS and fixed effects show significant negative relationships between manager religiosity and advertising expenditure. Only by including firm intrinsic religiosity, firm extrinsic religiosity, and social capital into the estimation does the positive relationship become evident (Model 2, Table 10). The firm religiosity variables likewise, are positively related to advertising expenditure. To determine which firm religiosity variable has the strongest influence on the relationship, I include interaction terms of the three firm religiosity variables with manager religiosity and regress these on advertising expenditure. We can see that the only statistically significant interaction term is between manager religiosity and firm intrinsic religiosity (Model 3, Table 10). The results in Table 10 suggests that religious managers typically incur lower advertising expenditures. However, social influence, particularly those arising from the firm's as well as the manager's socio-religious circle is strong enough to reverse their risk-aversion. 


\section{Macrothink}

Asian Journal of Finance \& Accounting

ISSN 1946-052X

2018, Vol. 10, No. 2

Table 10. Advertising expenditure on manager religiosity (OLS, firm-level fixed effects, and DPS-GMM)

\begin{tabular}{|c|c|c|c|c|c|c|c|c|c|}
\hline \multirow{2}{*}{$\begin{array}{l}\text { Risk Measure = } \\
\text { Advertising }\end{array}$} & \multicolumn{3}{|c|}{ OLS } & \multicolumn{3}{|c|}{ Fixed Effects } & \multicolumn{3}{|c|}{ DPS-GMM } \\
\hline & (1) & (2) & (3) & (1) & (2) & (3) & (1) & (2) & (3) \\
\hline \multirow[t]{2}{*}{ Manager Religiosity } & $-0.033 * * *$ & $0.038 * * *$ & $0.025 * * *$ & $-0.025 * * *$ & $0.029 * * *$ & $0.022 * * *$ & $-0.005 * *$ & $0.017 * * *$ & $0.014 * * *$ \\
\hline & $(0.179)$ & $(0.213)$ & $(0.158)$ & $(0.087)$ & $(0.098)$ & $(0.101)$ & $(0.224)$ & $(0.115)$ & $(0.204)$ \\
\hline Firm Intrinsic & & $0.027 * * *$ & $0.034 * * *$ & & $0.021 * * *$ & $0.028 * * *$ & & $0.024 * * *$ & $0.026^{* * *}$ \\
\hline Religiosity & & $(0.315)$ & $(0.149)$ & & $(0.105)$ & $(0.228)$ & & $(0.093)$ & $(0.101)$ \\
\hline Firm Extrinsic & & $0.051 * *$ & $0.043 * *$ & & $0.044 * *$ & $0.037 * *$ & & $0.018 * * *$ & $0.015^{* *}$ \\
\hline Religiosity & & $(0.261)$ & $(0.237)$ & & $(0.215)$ & $(0.374)$ & & $(0.065)$ & $(0.109)$ \\
\hline \multirow[t]{2}{*}{ Social Capital } & & $0.019 * *$ & $0.014^{*}$ & & $0.013^{*}$ & 0.011 & & $0.009^{*}$ & 0.005 \\
\hline & & $(0.306)$ & $(0.244)$ & & $(0.153)$ & $(0.251)$ & & $(0.126)$ & $(0.249)$ \\
\hline Manager Religiosity $\times$ & & & $0.058 * * *$ & & & $0.045^{* * *}$ & & & $0.033^{* * *}$ \\
\hline Firm Intrinsic & & & $(0.338)$ & & & $(0.193)$ & & & $(0.097)$ \\
\hline \multicolumn{10}{|l|}{ Religiosity } \\
\hline Manager Religiosity $\times$ & & & 0.034 & & & 0.025 & & & 0.011 \\
\hline Firm Extrinsic & & & $(0.168)$ & & & $(0.133)$ & & & $(0.088)$ \\
\hline \multicolumn{10}{|l|}{ Religiosity } \\
\hline Manager Religiosity $x$ & & & 0.007 & & & 0.008 & & & 0.004 \\
\hline Social Capital & & & $(0.334)$ & & & $(0.287)$ & & & $(0.413)$ \\
\hline \multirow[t]{2}{*}{ Board Size } & $0.025^{* *}$ & $0.021 * *$ & $0.013^{*}$ & $0.022 * * *$ & $0.019 * *$ & 0.009 & $0.016^{*}$ & $0.012^{*}$ & 0.009 \\
\hline & $(0.384)$ & $(0.277)$ & $(0.386)$ & $(0.176)$ & $(0.259)$ & $(0.181)$ & $(0.154)$ & $(0.105)$ & $(0.134)$ \\
\hline \multirow[t]{2}{*}{ Board Independence } & $0.033^{*}$ & $0.028 *$ & 0.020 & $0.028 * *$ & $0.023^{*}$ & $0.016^{*}$ & 0.021 & 0.017 & 0.011 \\
\hline & $(0.411)$ & $(0.388)$ & $(0.277)$ & $(0.233)$ & $(0.368)$ & $(0.334)$ & $(0.222)$ & $(0.163)$ & $(0.233)$ \\
\hline Director & $0.019^{* *}$ & $0.016^{*}$ & 0.011 & 0.015 & 0.011 & 0.008 & 0.008 & 0.005 & 0.003 \\
\hline Connectedness & $(0.241)$ & $(0.415)$ & $(0.458)$ & $(0.091)$ & $(0.086)$ & $(0.141)$ & $(0.365)$ & $(0.152)$ & $(0.211)$ \\
\hline \multirow[t]{2}{*}{ Return on Equity } & $0.035^{* *}$ & $0.027^{*}$ & $0.014^{*}$ & $0.029^{* *}$ & $0.018^{* *}$ & $0.014^{* *}$ & $0.013^{*}$ & $0.011 *$ & 0.006 \\
\hline & $(0.288)$ & $(0.195)$ & $(0.228)$ & $(0.178)$ & $(0.204)$ & $(0.355)$ & $(0.422)$ & $(0.222)$ & $(0.148)$ \\
\hline \multirow[t]{2}{*}{$\operatorname{Ln}(1+$ Sales Growth $)$} & $0.055^{* * *}$ & $0.041 * *$ & $0.022 *$ & $0.043 * * *$ & $0.032 * *$ & $0.017^{* *}$ & $0.015^{*}$ & 0.009 & 0.004 \\
\hline & $(0.333)$ & $(0.280)$ & $(0.165)$ & $(0.247)$ & $(0.166)$ & $(0.200)$ & $(0.331)$ & $(0.271)$ & $(0.181)$ \\
\hline \multirow[t]{2}{*}{ Surplus Cash } & $-0.046^{* * *}$ & $-0.036^{*}$ & $-0.021^{*}$ & $-0.033^{* *}$ & $-0.026^{* *}$ & $-0.015^{*}$ & $-0.024 * *$ & -0.012 & -0.007 \\
\hline & $(0.318)$ & $(0.248)$ & $(0.273)$ & $(0.143)$ & $(0.235)$ & $(0.118)$ & $(0.443)$ & $(0.338)$ & $(0.264)$ \\
\hline \multirow[t]{2}{*}{ Dividends } & $-0.015^{*}$ & $-0.011^{*}$ & -0.008 & $-0.010^{*}$ & -0.008 & -0.005 & -0.003 & -0.002 & -0.001 \\
\hline & $(0.277)$ & $(0.179)$ & $(0.333)$ & $(0.192)$ & $(0.217)$ & $(0.373)$ & $(0.318)$ & $(0.415)$ & $(0.189)$ \\
\hline \multirow[t]{2}{*}{ Manager Age } & $-0.051 * *$ & $-0.043 * *$ & $-0.029 *$ & $-0.046^{* *}$ & -0.033 & -0.014 & $-0.029 *$ & -0.015 & -0.011 \\
\hline & $(0.268)$ & $(0.367)$ & $(0.232)$ & $(0.110)$ & $(0.241)$ & $(0.123)$ & $(0.481)$ & $(0.503)$ & $(0.221)$ \\
\hline \multirow[t]{2}{*}{ Manager Experience } & $0.017 * * *$ & $0.012 *$ & $0.008^{*}$ & $0.014^{* *}$ & $0.011^{*}$ & 0.005 & $0.003^{*}$ & $0.002 *$ & $0.001^{*}$ \\
\hline & $(0.192)$ & $(0.215)$ & $(0.179)$ & $(0.238)$ & $(0.378)$ & $(0.244)$ & $(0.391)$ & $(0.402)$ & $(0.333)$ \\
\hline \multirow[t]{2}{*}{ Risk Measure (lag 1) } & & & & & & & $0.392^{* *}$ & $0.277^{* *}$ & $0.181^{*}$ \\
\hline & & & & & & & $(0.568)$ & $(0.443)$ & $(0.200)$ \\
\hline \multirow[t]{2}{*}{ Risk Measure (lag 2) } & & & & & & & $0.190^{*}$ & $0.176^{*}$ & 0.123 \\
\hline & & & & & & & $(0.333)$ & $(0.288)$ & $(0.138)$ \\
\hline
\end{tabular}




\section{Table 10 continued}

0.526

$\begin{array}{lll}3,280 & 3,280 & 3,280 \\ 0.553 & 0.589 & 0.477\end{array}$

$$
3,280
$$

3,280

3,280

3,280

3,280

This table reports ordinary least squares (OLS), firm-level fixed effects, and dynamic panel system GMM (DPS-GMM) estimations of advertising expenditure on manager religiosity and control variables. All models include year and industry dummy variables. Intercepts were included but not reported here. Cluster-robust standard errors (for OLS), within-cluster heteroscedasticity and serial correlation (for fixed effects) and finite-sample (for DPS-GMM) robust standard errors are reported in parentheses. ***, **, and * denotes statistical significance at the $1 \%, 5 \%$ and $10 \%$ respectively.

\section{Discussion}

The results show that manager religiosity affects firm risk-taking, after controlling for other determinants of risk-taking behavior including firm intrinsic and extrinsic religiosity, social capital of the district where the firm is headquartered, and institutional ownership. However, the results suggest a fair amount of social pressure on religious managers. For example, although religious managers are risk-averse, the effects are more pronounced for firms with high intrinsic religiosity. The literature suggests that followers of the Abrahamic faiths are generally more risk-averse. This is not the case in Malaysia. While managers of Christian firms show an aversion towards risk, managers of Islamic firms seem to be risk-takers, especially in terms of leverage and investment in fixed assets. Islam, from the writings contained within the Quran, strongly advocates entrepreneurship and acknowledges risk-taking as an essential element of business, which may explain this observation. The effects may be amplified by government policies that provide loose lines of credit for Malays or Bumiputeras (many of whom are Muslims), on top of other policies and initiatives that seek to provide them with additional economic support such as discounts on real-estate investment (Cheong and Sinnakkannu, 2014). Religious managers also spent less on advertising but then spend more once firm intrinsic religiosity was included in the model. In accordance with social norm theory, it may imply that pressure from the manager's socio-religious circle influenced them to behave in contrary ways.

The effects of religiosity on risk-taking is not limited to managers alone. Substituting the risk-taking measures with equity risk revealed that religiosity also has an impact on market decisions. Specifically, firm intrinsic religiosity reduces total risk and systematic risk but not idiosyncratic risk while manager religiosity reduced systematic and idiosyncratic risk, suggesting a greater level of cultural entanglement and religious influence on financial decision-making than previously thought. Religious managers are more confident and better able to adjust to their environment (Gebauer et al., 2012) and so will be better equipped to handle the demands placed on them, inspiring greater confidence from within the firm and the financial markets. Religiosity-driven behavior is nevertheless, secondary in the face of strong external monitoring mechanisms. Firms and managers are still subject to the oversight and controls imposed by a strong presence of institutional owners. Only in the absence of oversight by institutional owners do we see religiosity influencing risk-taking. The same can also be said of the market's response (i.e. total and systematic risk) towards religiosity. 


\subsection{Theoretical and practical implications}

First, studying the effects of religiosity on risk-taking at the micro-level allowed us to establish a direct link between an individual's religious devotion and his/her propensity to take risks, in the context of managerial decisions. Furthermore, by examining the religiosity of all layers of management, we are able to capture the influence of religiosity on different levels of authority in the decision-making process in a public firm. Allowing managers to self-report their religious devotion, also accounts for any socio-religious environment effects on the manager's behavior.

Second, social pressure causes religious managers to behave in peculiar ways. In a pluralistic market, religious managers may choose to increase advertising expenditure to appeal to the imaginations of the locals (Abela, 2014) in efforts to make themselves and/or the firm appear more devout, conform to social expectations and win over social favour and goodwill (Hopkins et al., 2014). As regional effects in terms of culture and behaviour have been found to affect firm performance (Burrus et al., 2018), firms headquartered in religious districts are also likely to be less risky due to the influence of religious local residents (Brammer et al., 2007). Managers in these districts likewise are thus more likely to be more religious and display greater risk-aversion.

Third, many studies in the finance literature have tended to categorize religion in a binary fashion (i.e. East and West). Religion however, transcends geographical borders. The differences between religions in terms of philosophy and practice especially regarding their impact on firms cannot be stressed enough. The findings in this study is testament to this fact.

Finally, in 2018, firms are increasingly pressured to have more inclusive and diverse workforces but remain hesitant owing to a lack of evidence on its benefits. Findings from this research are particularly beneficial to firms looking to implement or improve their cultural inclusiveness as it provides evidence that, religious managers are more calm, stable, and resilient (Gebauer et al., 2012) and are thus less likely to make hasty, risky decisions than non-religious managers, inspiring greater confidence from financial markets. Firms that have yet to take religious diversity into consideration when hiring new managers may finally be motivated to do so from the findings of this study. Additionally, we cannot downplay the significance of socio-religious pressure on firm risk especially in a pluralistic market. Firms whose employees that are predominantly of a particular religion may choose to establish operations in ceteris paribus, highly religious districts so as to build goodwill and trust, taking advantage of the local market's greater sense of confidence in the firm.

\section{Conclusion}

In their haste to become more culturally inclusive, firms fail to form a deeper understanding of race, religion and/or culture and how these affect the decision-making process. In this study I used micro-level data on the religiosity of managers in Malaysian public firms to examine how religion influences risk-taking. In so doing, I avoid the pitfalls of prior studies that tended to ignore the subtle nuances of religious philosophy. From this study, it is clear that regardless of religion, religious managers are generally more risk-averse. However, 
managers in Malaysia - Muslim, in particular - are susceptible to social pressures. The evidence also suggests that it is not only the managers that are susceptible to social pressure. Firm equity risk is also sensitive towards the religiosity of the district where the firm is based, suggesting that religious pressure has further-reaching effects on a firm than mere managerial behavior.

This study is not without its limitations. First, firm religion was defined as the majority religion of the firm. There is some degree of generalization in this definition which dampens socio-religious dynamics, hence further research should study each religious manager separately to find out how their religion influences their decision-making process at every step. Second, I only studied the four main religions of the world. Further research should ideally explore the influence of other religions (e.g. Judaism, Sikhism, Aboriginal beliefs) to construct a more holistic understanding of how religion shapes a firm. Future research may also want to explore how the belief in the non-existence of god(s) (i.e. Atheism) or the contemporary understanding of spiritualism i.e. the well-being of the 'mind-body-spirit' (Heelas, 2009) influences this process. Finally, are there other demographic (e.g. ethnicity, gender, socio-economic status) or psychographic (e.g. values, interests, opinions) factors that might moderate the influence of religion? With a rich variety of questions arising from this study, the time is right to start humanizing finance literature.

\section{Notes}

Note 1. In Malaysia, every citizen is by law, required to have a religion. While religious conversion is permitted, there have been many instances where Muslims were denied a change of religion by the National Registration Department, even though they no longer practice it (Samuri and Quraishi, 2014).

Note 2. Malaysia is often characterized culturally, economically, and politically by its pluralism. The 2010 national census showed that of its 28.7 million population, $67 \%$ were Malays or Bumiputeras, $25 \%$ were Chinese, $7 \%$ were Indians while the remaining $1 \%$ consisted of various smaller ethnic groups.

Note 3. Many social and legal issues in Malaysia are religiously-driven. This was again brought to attention after a recent ruling by the country's apex court on the religious conversion of minors split public opinion into two camps (Teoh and Rodzi, 2018; Nokman, 2018).

Note 4. As the survey was conducted annually, changes to the composition of managers will be reflected in the religiosity scores for the corresponding year. I thank the anonymous reviewer for making this clarification.

Note 5. I excluded the East Malaysian states of Sabah, Sarawak, and Labuan due to the unavailability of data.

Note 6 . For brevity, these results are not shown here. I am happy to provide them on request.

\section{References}

Abela, A. V. (2014). Appealing to the imagination: Effective and ethical marketing of religion, Journal of Business Research, 67, 50-58. https://doi.org/10.1016/j.jbusres.2013.03.011 
Anderson, R.C., \& Reeb, D.M. (2003). Founding-family ownership, corporate diversification, and firm leverage. The Journal of Law and Economics, 46, 653-684. https://doi.org/10.1086/377115

Arellano, M., Bover, O. (1995). Another look at the instrumental variable estimation of error-components models. Journal of Econometrics, 68, 29-51. https://doi.org/10.1016/0304-4076(94)01642-D

Barinov, A. (2017). Institutional ownership and aggregate volatility risk. Journal of Empirical Finance, 40, 20-38. https://doi.org/10.1016/j.jempfin.2016.11.003

Barro, R. J., \& McCleary, R. M. (2003). Religion and economic growth across countries. American Sociological Review, 68(5), 760-781. https://doi.org/10.2307/1519761

Benabou, R., \& Tirole, J. (2003). Intrinsic and extrinsic motivation. The Review of Economic Studies, 70(3), 489-520. https://doi.org/10.1111/1467-937X.00253

Bedard, J. C., \& Johnstone, K. M. (2004). Earnings manipulation risk, corporate governance risk, and auditors' planning and pricing decisions. The Accounting Review, 79(2), 277-304. https://www.jstor.org/stable/3203245

Bertrand, M., \& Schoar, A. (2003). Managing with style: The effect of managers on firm policies. The Quarterly Journal of Economics, 118, 1169-1208. https://www.jstor.org/stable/25053937

Blundell, R., \& Bond, S. (1998). Initial conditions and moment restrictions in dynamic panel data models. Journal of Econometrics, 87, 115-143. https://doi.org/10.1016/S0304-4076(98)00009-8

Brammer, S., Williams, G., \& Zinkin, J. (2007). Religion and attitude to corporate social responsibility in a large cross-county sample. Journal of Business Ethics, 71(3), 229-243. https://doi.org/10.1007/s10551-006-9136-z

Bushee, B. J., \& Noe, C. F. (2000). Corporate disclosure practices, institutional investors, and stock return volatility. Journal of Accounting Research, 38, 171-202. https://doi.org/10.2307/2672914/

Burrus, R. T., Graham, J. E., \& Jones, A. T. (2018). Regional innovation and firm performance. Journal of Business Research, 88, 357-362. https://doi.org/10.1016/j.jbusres.2017.12.042

Cheong, C. W. H., Sinnakannu, J. (2014). Ethnic diversity and firm financial performance: Evidence from Malaysia, Journal of Asia-Pacific Business, 15, 73-100. https://doi.org/10.1080/10599231.2014.872973

Cheong, C. W. H., Sinnakkannu, J., \& Ramasamy, S. (2017). Reactive or Proactive? Investor sentiment as a driver of corporate social responsibility. Research in International Business and Finance, 42, 572 - 582. https://doi.org/10.1016/j.ribaf.2017.07.002

Cialdini, R. B., Goldstein, N. J. (2004). Social influence: Compliance and conformity. Annual 
Review of Psychology, 55, 591-621. https://doi.org/10.1146/annurev.psych.55.090902.142015

Cicero, D., Wintoki, M.B., \& Yang, T. (2013). How do public companies adjust their board structures? Journal of Corporate Finance, 23, 108-127. https://doi.org/10.1016/j.jcorpfin.2013.08.001

Diaz, J. (2000). Religion and gambling in sin-city: a statistical analysis of the relationship between region and gambling patterns in Las Vegas residents. Social Science Journal, 37, 453-458. https://doi.org/10.1016/S0362-3319(00)00083-5

Fama, E., \& French, K. (1993). Common risk factors in the returns on stocks and bonds. Journal of Financial Economics, 33(1), 3-56. https://doi.org/10.1016/0304-405X(93)90023-5

Fama, E.F., \& Jensen, M.C. (1983). Separation of ownership and control. The Journal of Law and Economics, 26, 301-325. https://www.jstor.org/stable/725104

Farrell, K. A., \& Hersch, P. L. (2005). Additions to corporate boards: the effect of gender. Journal of Corporate Finance, 11, 85-106. https://doi.org/10.1016/j.jcorpfin.2003.12.001

Festre, A. (2010). Incentives and social norms: A motivation-based economic analysis of social norms. Journal of Economic Surveys, 24(3), 511-538. https://doi.org/10.1111/j.1467-6419.2009.00594.x

Fich, E.M., \& Shivdasani, A. (2007). Financial fraud, director reputation, and shareholder $\begin{array}{llll}\text { wealth. Journal of } & \text { Financial } & \text { Economics, } & \text { 86, } 336 .\end{array}$ https://doi.org/10.1016/j.jfineco.2006.05.012

Gasper, K., \& Clore, G. (1998). The persistent use of negative affect by anxious individuals to estimate risk. Journal of Personality and Social Psychology, 74, 1350-1363.

Gebauer, J. E., Sedikides, C., \& Neberich, W. (2012). Religiosity, social self-esteem, and psychological adjustment: On the cross-cultural specificity of the psychological benefits of $\begin{array}{llll}\text { religiosity. } & \text { Psychological } & \text { Science, } & \text { 23, }\end{array}$ https://doi.org/10.1177\%2F0956797611427045

Geyer, A. L., \& Baumeister, R. F. (2005). Religion, morality, and self-control: Values, virtues, and vices. In R. F. Paloutzian \& C. L. Park (Eds.), Handbook of the psychology of religion and spirituality (pp. 412-432). New York: Guilford Press.

Granger, K., Lu, V. N., Conduit, J., Veale, R., \& Habel, C. (2014). Keeping the faith! Drivers of participation in spiritually-based communities. Journal of Business Research, 67, 68-75. https://doi.org/10.1016/j.jbusres.2013.03.013

Grant, A. M., Gino, F., \& Hofmann, D. A. (2011). Reversing the extraverted leadership advantage: The role of employee proactivity. Academy of Management Journal, 54, 528-550. https://doi.org/10.5465/amj.2011.61968043

Graves, S. B., \& Waddock, S. A. (1990). Institutional ownership and control: Implications for long-term corporate strategy. The Executive, 4(1), 75-83. https://www.jstor.org/stable/4164935 
Guiso, L., Sapienza, P., \& Zingales, L. (2003). People's opium? Religion and economic attitudes. Journal of Monetary Economics, 50, 225-282. https://doi.org/10.1016/S0304-3932(02)00202-7

Gul, F.A., \& Ng, A.C. (2016). Auditee religiosity, external monitoring, and the pricing of audit services. Journal of Business Ethics, https://doi.org/10.1007/s10551-016-3284-6

Heelas, P. (2009). Spiritualities of life: New Age romanticism and consumptive capitalism. Blackwell Publishing, Oxford, UK.

Hilary, G., \& Hui, K. W. (2009). Does religion matter in corporate decision making in America? Journal of Financial Economics, 93(3), 455-473. https://doi.org/10.1016/j.jfineco.2008.10.001

Hopkins, C. D., Shanahan, K. J., \& Raymond, M. A. (2014). The moderating role of religiosity on non-profit advertising. Journal of Business Research, 67, 23-31. https://doi.org/10.1016/j.jbusres.2013.03.008

Iannaccone, L.R. (1998). Introduction to the economics of religion, Journal of Economic Literature, 36, 1465-1495. https://www.jstor.org/stable/2564806

Jafarinejad, M., Jory, S. R., \& Ngo, T. N. (2015). The effects of institutional ownership on the value and risk of diversified firms. International Review of Financial Analysis, 40, 207-219. https://doi.org/10.1016/j.irfa.2015.05.019

Jaggi, B., \& Xin, H. (2014). Religiosity and audit fees. Working paper, The State University of New Jersey-Rutgers Business School.

Jha, A., \& Chen, Y. (2015). Audit fees and social capital, The Accounting Review, 90(2), 611-639. https://doi.org/10.2308/accr-50878

Jiang, F., Jiang, Z., Kim, K. A., \& Zhang, M. (2015). Family-firm risk-taking: Does religion matter? Journal of Corporate Finance, 33, 260-278. https://doi.org/10.1016/j.jcorpfin.2015.01.007

Kaplan, S.N., Klebanov, M.M., \& Sorensen, M. (2012). Which CEO characteristics and abilities matter? Journal of Finance, 67, 973-1007. https://doi.org/10.1111/j.1540-6261.2012.01739.x

Kohlberg, L. (1984). Essays on moral development, 2. The psychology of moral development. New York: Harper and Row.

Leventis, S., Dedoulis, E., \& Abdelsalam, O. (2015). The impact of religiosity on audit pricing. Journal of Business Ethics, 148(1), 53-78. https://doi.org./10.1007/s10551-015-3001-x.

Masulis, R.W., Mobbs, S.H. (2014). Independent director incentives: where do talented directors spend their limited time and energy? Journal of Financial Economics, 111, 406-429. https://doi.org/10.1016/j.jfineco.2013.10.011 
McDaniel, S. W., \& Burnett, J. J. (1990). Consumer religiosity and retail store evaluative criteria. Journal of the Academy of Marketing Science, 18(2), 101-112. https://doi.org/10.1007/BF02726426

Miller, A.S. (2000). Going to hell in Asia: the relationship between risk and religion in a cross-cultural setting. Review of Religious Research, 40, 5-18. https://doi.org/10.2307/3512141

Miller, A.S., \& Hoffmann, J.P. (1995). Risk and religion: an explanation of gender differences in religiosity. Journal for the Scientific Study of Religion, 34, 63-75. https://doi.org/10.2307/1386523

Minton, E. A., Kahle, L. R., \& Kim, C. H. (2015). Religion and motives for sustainable behaviours: A cross-cultural comparison and contrast. Journal of Business Research, 68, 1937-1944. https://doi.org/10.1016/j.jbusres.2015.01.003

Mollick, E. (2012). People and process, suits and innovators: The role of individuals in firm performance, Strategic Management Journal, 33, 1001-1015. https://doi.org/10.1002/smj.1958

Morck, R., Shleifer, A., \& Vishny, R. (1988). Management ownership and market valuation: an empirical analysis. Journal of Financial Economics, 20, 293-315. https://doi.org/10.1016/0304-405X(88)90048-7

Moss K. R. (1982). The middle manager as innovator, Harvard Business Review, 60(7), 94-106.

Nokman, F. S. (2018, January 30). Mixed reactions to Federal Court's decision in Indira Ghandi's case, New Straits Times, accessed 10 February 2018 from https://www.nst.com.my/news/crime-courts/2018/01/330408/mixed-reactions-federal-courtsdecision-indira-ghandis-case

Norenzayan, A., \& Shariff, A. F. (2008). The origin and evolution of religious prosociality, Science, 322(5898), 58-62. https://doi.org/10.1126/science.1158757

Parboteeah, K. P., Hoegl, M., \& Cullen, J. B. (2008). Ethics and religion: An empirical test of a multidimensional model. Journal of Business Ethics, 80(2), 387-398. https://doi.org/10.1007/s10551-007-9439-8

Roodman, D. (2009). How to do xtabond2: an introduction to difference and system GMM in Stata, The Stata Journal, 9, 86-136.

Rupasingha, A., \& Goetz, S. J. (2008). U.S. County-Level Social Capital Data, 1990-2005. University Park, PA: The Northeast Regional Center for Rural Development, The Pennsylvania State University.

Sah, R.K., \& Stiglitz, J.E. (1986). The architecture of economic systems. The American Economic Review, 76, 716-727. https://www.jstor.org/stable/1806069

Sah, R.K., \& Stiglitz, J.E. (1991). The quality of managers in centralized versus decentralized 
organizations. Quarterly Journal of Economics, 106, 289-295. https://doi.org/10.2307/2937917

Samuri, M. A., \& Quraishi, M. (2014). Negotiating apostasy: Applying to "Leave Islam" in Malaysia. Islam and Christian-Muslim Relations, 25, 507-523. https://doi.org/10.1080/09596410.2014.907054

Schultz, P. W., Zelezny, L., \& Dalrymple, N. J. (2000). A multinational perspective on the relation between Judeo-Christian religious beliefs and attitudes of environmental concern. Environment and Behavior, 32(4), 576-591. https://doi.org/10.1177\%2F00139160021972676

Sedikides, C., \& Gebauer, J. E. (2010). Religiosity as self-enhancement: A meta-analysis of the relation between socially desirable responding and religiosity. Personality and Social Psychology Review, 14, 17-36. https://doi.org/10.1177/1088868309351002

Shariff, A. F., \& Norenzayan, A. (2007). God is watching you priming god concepts increases prosocial behavior in an anonymous economic game. Psychological Science, 18(9), 803-809.

Sila, V., Gonzalez, A., \& Hagendorff, J. (2016). Women on board: Does boardroom gender diversity affect firm risk? Journal of Corporate Finance, 36, 26-53. https://doi.org/10.1016/j.jcorpfin.2015.10.003

Stavrova, S., \& Siegers, P. (2014). Religious prosociality and morality across cultures: How social enforcement of religion shapes the effects of personal religiosity on prosocial and moral attitudes and behaviours. Personality and Social Psychology Bulletin, 40(3), 315-333. https://doi.org//10.1177/0146167213510951

Stern, P. C. (2000). New environmental theories: Toward a coherent theory of environmentally significant behavior. Journal of Social Issues, 56(3), 407-424.

Stulz, R.M., \& Williamson, R. (2003). Culture, openness, and finance. Journal of Financial Economics, 70, 313-349. https://doi.org/10.1016/S0304-405X(03)00173-9

Sunstein, C. R. (1996). Social norms and social roles. Columbia Law Review, 96(4), 903-968. https://doi.org/10.2307/1123430

Teoh, S., \& Rodzi, N. H. (2018, January 29). Malaysia's highest court rules unilateral conversion of children to Islam void in Indira case, The Straits Times, accessed 10 February 2018 from http://www.straitstimes.com/asia/se-asia/unilateral-conversion-of-indira-gandhis

-3-children-is-null-void-federal-court

Windmeijer, F. (2005). A finite sample correction for the variance of linear efficient two-step GMM estimators. Journal of Econometrics, 126, 25-51. https://doi.org/10.1016/j.jeconom.2004.02.005

Wintoki, M.B., Linck, J.S., \& Netter, J.M. (2012). Endogeneity and the dynamics of internal corporate governance. Journal of Financial Economics, 105, 581-606. https://doi.org/10.1016/j.jfineco.2012.03.005 
Appendix

Table A1. Definition of Variables

\begin{tabular}{|c|c|}
\hline Variable & Definition \\
\hline \multicolumn{2}{|l|}{ Risk Measures } \\
\hline Leverage & Total debt to total assets \\
\hline Fixed Assets & Capital expenditure to total assets \\
\hline $\mathrm{R} \& \mathrm{D}$ & Research and development expenditure to total assets \\
\hline Advertising & Advertising expenditure to total assets \\
\hline \multicolumn{2}{|l|}{ Religiosity Measures } \\
\hline Manager Religiosity & $\begin{array}{l}\text { Combined sum of religion scores from each level of } \\
\text { management multiplied by their assigned weights divided by } \\
\text { the number of employees in the firm }\end{array}$ \\
\hline Firm Intrinsic Religiosity & $\begin{array}{l}\text { The percentage of religious adherents in the population of the } \\
\text { district where the sample firm is headquartered }\end{array}$ \\
\hline Firm Extrinsic Religiosity & $\begin{array}{l}\text { The number of religious institutions in the district where the } \\
\text { sample firm is headquartered }\end{array}$ \\
\hline Social Capital & $\begin{array}{l}\text { An index constructed following Rupasingha and Goetz (2008) } \\
\text { and Jha and Chen (2015) }\end{array}$ \\
\hline \multicolumn{2}{|l|}{ Board Characteristics } \\
\hline Board Size & Number of directors on the board \\
\hline Board Independence & $\begin{array}{l}\text { Number of independent directors divided by number of } \\
\text { directors }\end{array}$ \\
\hline Director Connectedness & Total number of external board seats held by all directors \\
\hline \multicolumn{2}{|l|}{ Firm Characteristics } \\
\hline Return on Equity & Net income to total equity \\
\hline Ln $(1+$ Sales Growth $)$ & Natural logarithm of $1+$ sales growth; a proxy for firm size \\
\hline Surplus Cash & $\begin{array}{l}\text { Net cash flow from operating activities less depreciation and } \\
\text { amortization plus research and development expenditure } \\
\text { divided by book value of total assets }\end{array}$ \\
\hline Dividends & Dichotomous variable that is ' 1 ' if the firm pays dividends \\
\hline Manager Age & Average age of managers in the firm \\
\hline Manager Experience & $\begin{array}{l}\text { Average number of years managers has been employed in the } \\
\text { firm in a managerial position }\end{array}$ \\
\hline
\end{tabular}




\section{Copyright Disclaimer}

Copyright for this article is retained by the author(s), with first publication rights granted to the journal.

This is an open-access article distributed under the terms and conditions of the Creative Commons Attribution license (http://creativecommons.org/licenses/by/3.0/). 